\title{
Enodicalix (Diploporita, Aristocystitidae): A new echinoderm genus from the Middle Ordovician of Spain
}

\author{
C.R.C Paul ${ }^{1}$ and J.C. Gutiérrez-Marco² \\ ${ }^{1}$ School of Earth Sciences, University of Bristol \\ Bristol, BS8 1RJ, UK. E-mail: glcrcp@bris.ac.uk \\ ${ }^{2}$ Instituto de Geociencias (CSIC, UCM), and Departamento de Geodinámica, \\ Estratigrafía y Paleontología, Facultad CC. Geológicas \\ José Antonio Novais 12, E-28040 Madrid, Spain. E-mail: jcgrapto@ucm.es
}

\begin{abstract}
Restudy of an Ordovician diploporite specimen from the Middle Ordovician of central Spain reveals that the species 'Calix' inornatus MELÉNDEZ has four ambulacra, each with two equal facets, an oval hydropore and a smooth thecal surface. In contrast, the type species of Calix has four ambulacra, each with four facets added in a clockwise direction during growth, a trilobed hydropore, and a theca with spiny plates. Other aristocystitid genera with four ambulacra have one facet per ambulacrum. 'Calix' inornatus differs from all other aristocystitid genera and warrants a new generic name, for which we propose Enodicalix.
\end{abstract}

\section{INTRODUCTION}

The Ordovician echinoderm fauna of Spain includes some diverse, but sometimes poorly known diploporite blastozoans (Arroyo and Lara, 2002, and references therein). In several cases these were first described and named on the basis of inadequate type material, such as partial internal moulds, often with no indication of the key characters that are today considered essential to determine their taxonomic affinities. Recent discoveries have improved our knowledge of the morphology of these species, which we are attempting to re-describe to modern standards, and where necessary introduce new names. This requires reviewing the evidence that relates the new material that preserves key characters to the originally described type material. In turn, this should help establish with greater certainty the essential characters of diploporite families, such as the Aristocystitidae, and hence clarify their evolutionary relationships. For example, it is now known that the Spanish Ordovician pentameral genus, Oretanocalix GUTIÉRREZ-MARCO, 2000, belongs in the family Aristocystitidae (Gutiérrez-Marco, 2000). This paper redescribes one such species, 'Calix' inornatus MELÉNDEZ, 1958, and shows that it cannot be accommodated within any existing aristocystitid genus, including Calix. The new generic name Enodicalix is proposed for it.

\section{HISTORICAL REVIEW}

Meléndez (1958, p. 326, pl. 1, fig. 1) described a new species of diploporite blastozoan from the Ordovician of the Montes de Toledo, Spain. His new species Calix inornatus 
was based on a unique type specimen that preserved only the internal mould of the aboral part of the theca. Thus, the external surface was unknown as were the details of the oral area, which is nowadays considered critical in determining the affinities of blastozoans. Meléndez chose the trivial name inornatus because the internal surface of the theca was basically smooth, except for the fillings of the canals of the diplopores. Most species of Calix have circlets of spiny plates aborally (see for example, Gutiérrez-Marco and Colmenar, 2011, pl. 1, p. 193), so the absence of any trace of spines was thought to be significant. In fact, matching internal and external moulds show that sometimes there is no trace of the spiny ornament on the inner surface of the theca (see Chauvel and Meléndez, 1978, pl. 1, figs. 1 and 2). Later, Chauvel and Meléndez (1978) described and illustrated some additional specimens under the names Calix inornatus and $C$. toledensis nov. sp., but these did not add significantly to knowledge of the species. It is worth pointing out that the aboral theca appears to have been more robust in Calix sensu lato, than the oral part, at least to judge by the frequency of preservation. Calix sedgwicki ROUAULT, 1851, the type species of Calix, and 'Calix' inornatus are the only two species of Calix sensu lato in which details of the oral area are known.

Gutiérrez-Marco and Aceñolaza (1999) described and illustrated a new specimen of Calix' inornatus found at the type locality of the species, which preserved the external surface of the adoral part of the theca. They reviewed the literature known to that date, described the morphology thoroughly and presented a revised diagnosis. This revision showed that ' $C$.' inornatus (Fig. 1A) was characterized by four ambulacra, each of which terminated in a pair of equal ambulacral facets developed on individual circum-oral plates and with obvious ambulacral orifices (GutiérrezMarco and Aceñolaza, 1999, pl. 2, fig. 1). The mouth is covered by relatively large cover plates, as in other aristocystitid diploporites. The hydropore is an irregular elongate structure set in a broadly oval tubercle with the adoral margin parallel to the posterior edge of the peristome. The gonopore is circular and set in a chimney-like tubercle apparently within a single thecal plate and the periproct is widely separated from the mouth, heptagonal with narrow ledges for the anal cover plates. The specimen also shows that the trivial name inornatus was most appropriate. The external surface is remarkably smooth, but with traces of small elongate oval diplopores that lack peripore rims.

Other aristocystitid genera have four ambulacra, but of these Lepidocalix TERMIER AND TERMIER, 1950, Glaphocystis CHAUVEL, 1966, Prokopius PAUL, 2018 and Sinocystis REED, 1917 all have a single facet in each ambulacrum. Calix sensu stricto (Fig. 1B) has four facets in each ambulacrum that are arranged in an arc and were added in a clockwise direction during growth. Phlyctocystis CHAUVEL, 1966 (Fig. 1C) has four ambulacra that each divide once to give eight ambulacral facets, but the eight branches are widely separated and from the only specimen that preserves the oral area two of the facets are developed on three thecal plates. In contrast the paired facets in ' $C$.' inornatus are side by side on a single circumoral plate and flush with the surface. Finally, Triamara TILLMAN, 1967 and Binocalix MCDERMOTT AND PAUL, 2019 have paired ambulacral facets on single circum-oral plates, but in both genera the facets are raised up in oral prominences and Triamara has only three ambulacra. The number of ambulacra in Binocalix is unknown, but it is also characterized by unusual diplopores that are polygonal
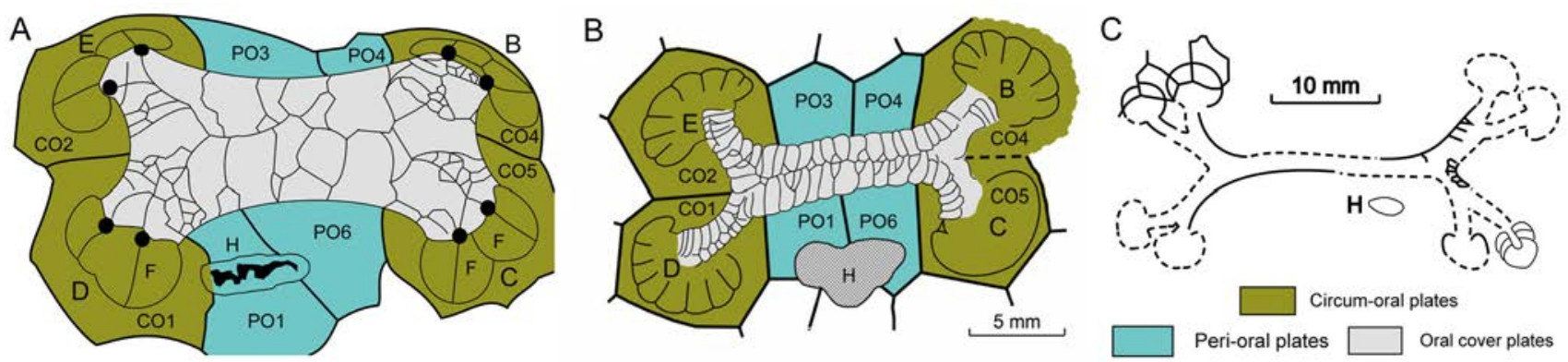

FIGURE 1. Diagrammatic representations of the oral areas of Enodicalix gen. nov. A) Calix RouAULT, 1851. B) Phlyctocystis cHAuvEL, 1966. C) In Enodicalix each circum-oral plate (CO1, CO2, CO4, C05) bears a pair of rounded facets (F). Food passed into the theca through small holes adjacent to the facets, the ambulacral orifices (black). The mouth was surrounded by eight plates, four central peri-orals (P01, P03, PO4, P06) and the four distal circum-orals. The posterior pair of peri-orals share the hydropore $(\mathrm{H})$, which is oval and parallel to the posterior margin of the mouth. The mouth is covered by immovable cover plates, crudely arranged in two series anterior and posterior. In Calix (B) the same oral plate arrangement occurs, but the four circum-orals each bear four facets for a cluster of brachioles (erect, biserial food-gathering structures). The hydropore (H) is crudely trilobed and extends onto the plates below P01 and P06. In Phlyctocystis (C) the four ambulacra are proportionately narrower and distally they divide into separate branches that terminate in a single facet, but in the upper left ambulacrum each facet appears to be developed on three plates, not a single circum-oral. The hydropore in this diagram is to the right. This is really exceptional in aristocystitid, indeed diploporite, blastozoans and suggests the diagram was drawn from an external mould, not a latex cast. If so, it is reversed with respect to left and right. For this reason, the ambulacra are not identified. B-E ambulacra B-E. A) new, B) redrawn from Chauvel, 1977, figure 1a, p. 315, C) redrawn from Chauvel, 1978, figure 5 b, p. 39. 
and have a central tubercle. They closely resemble those of the sphaeronitid subgenus Sphaeronites (Peritaphros) PAUL, 1973, but those of Calix gutierrezi CHAUVEL AND MELÉNDEZ, 1986, are also similar (Chauvel and Meléndez, 1986, fig. 1b).

Therefore, 'Calix' inornatus cannot easily be accommodated in any of the existing genera of aristocystitids, as pointed out by McDermott and Paul (2019, p. 531) and Paul (2018, p. 341). Due to the recent proposal for a new edition of the Treatise on Invertebrate Paleontology (Part S, Echinodermata, which will cover the Blastozoa), we consider it useful to establish a new generic name based on the Spanish material, which also has significance for the family level systematics of diploporite echinoderms.

\section{GEOLOGICAL SETTING}

Based on present evidence, the geographic and stratigraphic range of Enodicalix inornatus is restricted to a single locality (VPA, to the south of Las Ventas con Peña Aguilera, in the Montes de Toledo area, central Spain) in the lower part of the Navas de Estena Formation, in dark mudstones of early Oretanian age (early middle Darriwilian in terms of the global scale). From this classical locality for Spanish Ordovician fossils, placed ca. $39^{\circ} 31^{\prime} 21^{\prime \prime} \mathrm{N}, 4^{\circ} 11^{\prime} 56^{\prime \prime} \mathrm{W}$ in the right bank of the Acebrón stream valley (see detailed map in Rábano, 1985, fig. 1) we have the holotype (reillustrated by GutiérrezMarco and Aceñolaza, 1999, pl.1, fig. 3), the topotype with the oral area, and an additional topotype which consists of a fairly complete internal mould of an uncrushed theca, figured in Gutiérrez-Marco and Aceñolaza (1999, pl.1, fig. 1). In the same paper, Gutiérrez-Marco and Aceñolaza (1999) questioned attributions to this species of specimens from other provenances, that are taxonomically undeterminable. This is the case with the aboral internal mould from locality NE VII, specimen MT-63 of Chauvel and Meléndez (=Gutiérrez-Marco and Aceñolaza 1999, pl. 1, fig. 2), which shows a lateral deformation instead of an orally-inflated theca. They considered the species Calix toledensis CHAUVEL AND MELÉNDEZ, 1978, also defined from the type locality and horizon of $E$. inornatus, as a possible younger synonym of the former species. Its holotype is a poorly preserved internal mould with a rectangular peristome, and the remaining paratypes attributed to the species correspond to indeterminable fragments of aristocystitids with similar compactional flattening morphologies to the holotype (i.e., telescopic fractures of the theca: Gutiérrez-Marco and Aceñolaza, 1999). Owing to the lack of diagnostic characters in its definition, and being impossible to assign some other material to $C$. toledensis, the cited authors have proposed restricting $C$. toledensis to its holotype, at the same time that they consider it as a probable taphonomic variety of E. inornatus. The same opinion is followed here, so that all the new references to $C$. toledensis are considered as highly questionable from a taxonomic point of view.

\section{METHODS}

Latex casts were made from the critical external mould (MGM-2000-O) that preserves the details of the oral area. Latex casts and natural internal moulds were whitened with magnesium oxide or white fingerprint powder for photography. Stereophotographs were produced using a see-saw, which rotates specimens through approximately $12^{\circ}$. In the systematic descriptions, terminology follows Paul (1973) for general diploporite morphology and Paul (2017) for aristocystitid oral plating.

Repositories. Specimens are deposited in the Museo Geominero, Madrid (MGM) and the Departamento de Geodinámica, Estratigrafía y Paleontología, Universidad Complutense, Madrid (DPM).

\section{SYSTEMATIC PALAEONTOLOGY}

\section{Family: Aristocystitidae NEUMAYR, 1889}

Diagnosis. Directly attached diploporites with elongate oral area surrounded by at least eight plates (four central peri-orals [POO] and four distal circum-orals [COO]), and covered by two series of larger outer and smaller central cover plates; with 2-5 ambulacra bearing 1-5 brachioles each; with a large hydropore shared by plates PO1 and PO6 and often a spout-like gonopore usually within a single plate near the periproct; with thecal plates densely covered with diplopores that are frequently sealed externally by a thin epistereom and sometimes extended into spine-like projections.

Remarks. This diagnosis differs from recent preceding examples such as McDermott and Paul (2019, p. 530) in that Oretanocalix GUTIÉRREZ-MARCO, 2000, is now known to be an aristocystitid genus with five ambulacra and up to five facets per ambulacrum.

\section{GENUS Enodicalix gen. nov.}

Type species. Calix inornatus MELÉNDEZ, 1958, p. 326, figure 1, from the lower Oretanian of Las Ventas con Peña Aguilera (Toledo), Spain.

Diagnosis. An aristocystitid genus with smooth thecal surface, four ambulacra, each with an equal pair of rounded facets developed on a single circum-oral 
plate, large oval hydropore close to ambulacrum D, circular gonopore within a circular tubercle, heptagonal periproct, very little evidence of diplopores on the external surface.

Derivation of name. From the Latin enodis meaning 'without knots' and calix, masculine, 'a cup', in allusion to its relationship with the genus Calix ROUAULT, 1981.
Enodicalix inornatus (MELÉNDEZ, 1958) (Figs. 1-4)

1958 Calix inornatus nov. sp. - Meléndez, p. 326, fig. 1. 1978 Calix inornatus Meléndez - Chauvel and Meléndez, p. 79, pl. 1, figs. 7, 8, 9?, figs 5a, 5d (non figs. 5b, 5c = Aristocystitidae indet.)

?1978 Calix toledensis nov. sp. - Chauvel and Meléndez, p. 80 (specimens MT-043 and VP-091?), pl. 2, figs 2-3
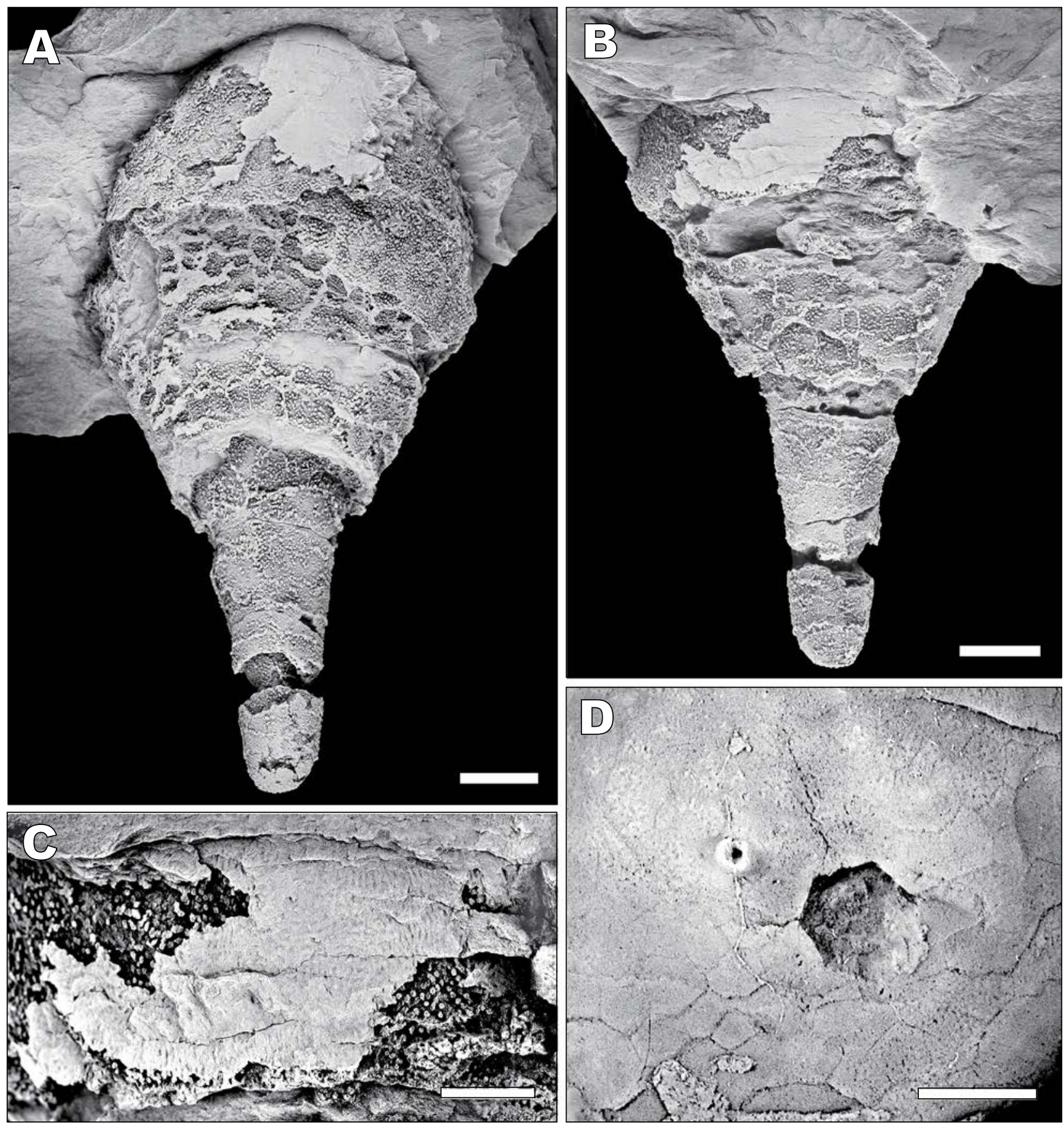

FIGURE 2. A) Internal mould MGM-2001-0, showing the overall shape of the theca. B) Reverse side of MGM-2001-0, showing small area that preserves thecal surface (top). C) Enlargement of figure (B) to right showing weak traces of diplopores on the external surface. D) Enlargement of latex cast of MGM-2000-O, showing weak traces of diplopores on external surface. Scale bars $A, B=10 \mathrm{~mm}, C, D=5 \mathrm{~mm}$. 
(non pl. 2, fig. 4 = Aristocystitidae indet.)

1983 Calyx (sic) inornatus Meléndez - Meléndez and Chauvel, p. 153.

1984 Calix inornatus Meléndez - Chauvel and Meléndez, in Gutiérrez-Marco et al., p. 431, figs. 2b and 2c? (non pl. 1, figs. 6-8; fig. 2a = Oretanocalix? sp.)

non 1992 Calyx/Calys (sic) inornatus Meléndez - Gil Cid and Bernal Barreiro, 1992 p. 475, pl. 2, fig. 1 (= Oretanocalix? sp.).

1993 Calix inornatus Meléndez - Gutiérrez-Marco, pp. $541,542$.

1999 Calix inornatus Meléndez - Gutiérrez-Marco and Aceñolaza, p. 563, pl. 1, figs. 1, 3-6, pl. 2, figs. 1-2.

2000 Calix inornatus Meléndez - Gutiérrez-Marco, p. 84, figs. $1 \mathrm{~g}$-i.

2002 Calix inornatus Meléndez - Arroyo and Lara, p. 96. non 2002 Calix toledensis Chauvel and Meléndez - Arroyo and Lara, p. 97.

non 2002 Calix cf. toledensis Chauvel and Meléndez Arroyo and Lara, p. 97.

2011 Calix? inornatus Meléndez - Gutiérrez-Marco and Colmenar, p. 190, 192, pl. 1, fig. 10.

2012 Calix inornatus Meléndez - Gil Cid and García Rincón, p. 186.

non 2013 Calix toledensis - Lefebvre et al., p. 181.

2017 Calix inornatus Meléndez - Makhlouf et al., p. 304, 307.

2018 Calix inornatus Meléndez - Paul, p. 340, 341.

2019 Calix inornatus Meléndez - McDermott and Paul, p.

531, fig. 5a-c, p. 532.

Holotype. The unique internal mould of the aboral part of a theca, illustrated by Meléndez (1958, fig. 1) and now in the Department of Geodynamics, Stratigraphy and Palaeontology, Universidad Complutense, Madrid (DPM MT-01). The only additional material accepted here is another internal mould (MGM-2001-O, Fig. 2A-C) and the matching internal and external moulds of (MGM-2000-O, Figs. 3 ; 4), on which the generic diagnosis is based (see discussion below).

Diagnosis. As for the genus, which is monotypic.
Description. In MGM-2000-O the theca is moderately large, approximately $30 \mathrm{~mm}$ in diameter (Fig. 4A) and up to $30 \mathrm{~mm}$ of the adoral theca is preserved (Fig. 4E). The internal mould (Fig. 2A, B) reaches over $100 \mathrm{~mm}$ and is incomplete. The oral surface is regularly rounded with the more or less rectangular peristome at the top (Figs. 3A, B; 4D). The four ambulacra extend about $13 \mathrm{~mm}$ from left to right, by a maximum of $8.5 \mathrm{~mm}$ from front to back, as measured to the outside of the rounded brachiole Facets (F, Figs. 1A; 3C). The oral groove reaches $8.3 \mathrm{~mm}$ left to right, by $3.5 \mathrm{~mm}$ front to back and is covered by cover plates. Each ambulacrum bears a pair of equal facets (Figs. 3A; 4B), reaching $2.0 \mathrm{~mm}$ across by about $1.5 \mathrm{~mm}$ radially and divided by a median radial ridge (Figs. $3 \mathrm{~A} ; 4 \mathrm{~B}$, lower left). At the adoral end of the ridge is an Ambulacral Orifice (AO) 0.25 to $0.3 \mathrm{~mm}$ across (Fig. 3C). In ambulacrum $\mathrm{E}$ the median ridges of the pair of facets are at $90^{\circ}$ to each other.

The plating around the mouth appears to conform with the usual aristocystitid pattern, with four more central PeriOral Plates (POO, Fig. 1A), two on the anterior side of the mouth and two on the posterior side which share the hydropore (H, Figs. 1A; 3C), plus at each end a pair of more distal Circum-Oral plates (COO, Fig. 1A) which bear the ambulacral Facets (F, Figs. 1A; 3C). Sutures between most of these plates can be seen on the internal mould (Fig. 4C).

The Hydropore (H, Figs. 1A; 3C; h, Fig. 4B) is an irregular slit set within an oval tubercle with a distinct rim $2.5 \mathrm{~mm}$ long by $0.9 \mathrm{~mm}$ wide. The tubercle is parallel to the posterior margin of the peristome and separated from it by $1.3 \mathrm{~mm}$ (Fig. 4B). The gonopore (g, Fig. 4B) is a rounded pore 1.1 by $0.7 \mathrm{~mm}$ across and set within a raised tubercle, also with a distinct rim $1.2 \mathrm{~mm}$ across. The gonopore lies below the $\mathrm{D}$ ambulacrum and separated from it by $7.6 \mathrm{~mm}$. It is also $2.3 \mathrm{~mm}$ from the nearest edge of the periproct.

The periproct (a, Fig. 4B, D) was probably seven-sided, about $4.2 \mathrm{~mm}$ across and none of the anal plates remains. The adoral side is $2.3 \mathrm{~mm}$ long.
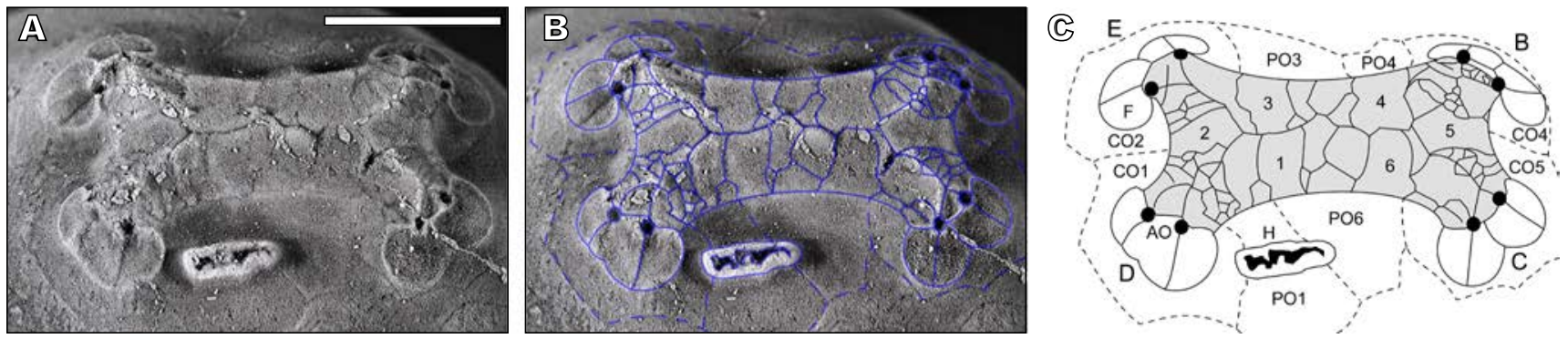

FIGURE 3. A) Detail of oral surface of latex cast of MGM-2000-0 to show ambulacra, hydropore and plate sutures. Scale bar= $5 \mathrm{~mm}$. B) Traces of oral frame plates (dashed lines) and cover plates (solid lines) superimposed over the oral surface. C) Interpretation of ambulacra and sutures of oral frame plates and cover plates (shaded). AO: Ambulacral Orifices (black); B-E: ambulacra B-E; C01-C05: Circum-Oral plates bearing ambulacral Facets (F), H: Hydropore; P01-P06: Peri-Oral plates. 1-6: possible primary oral cover plates. 

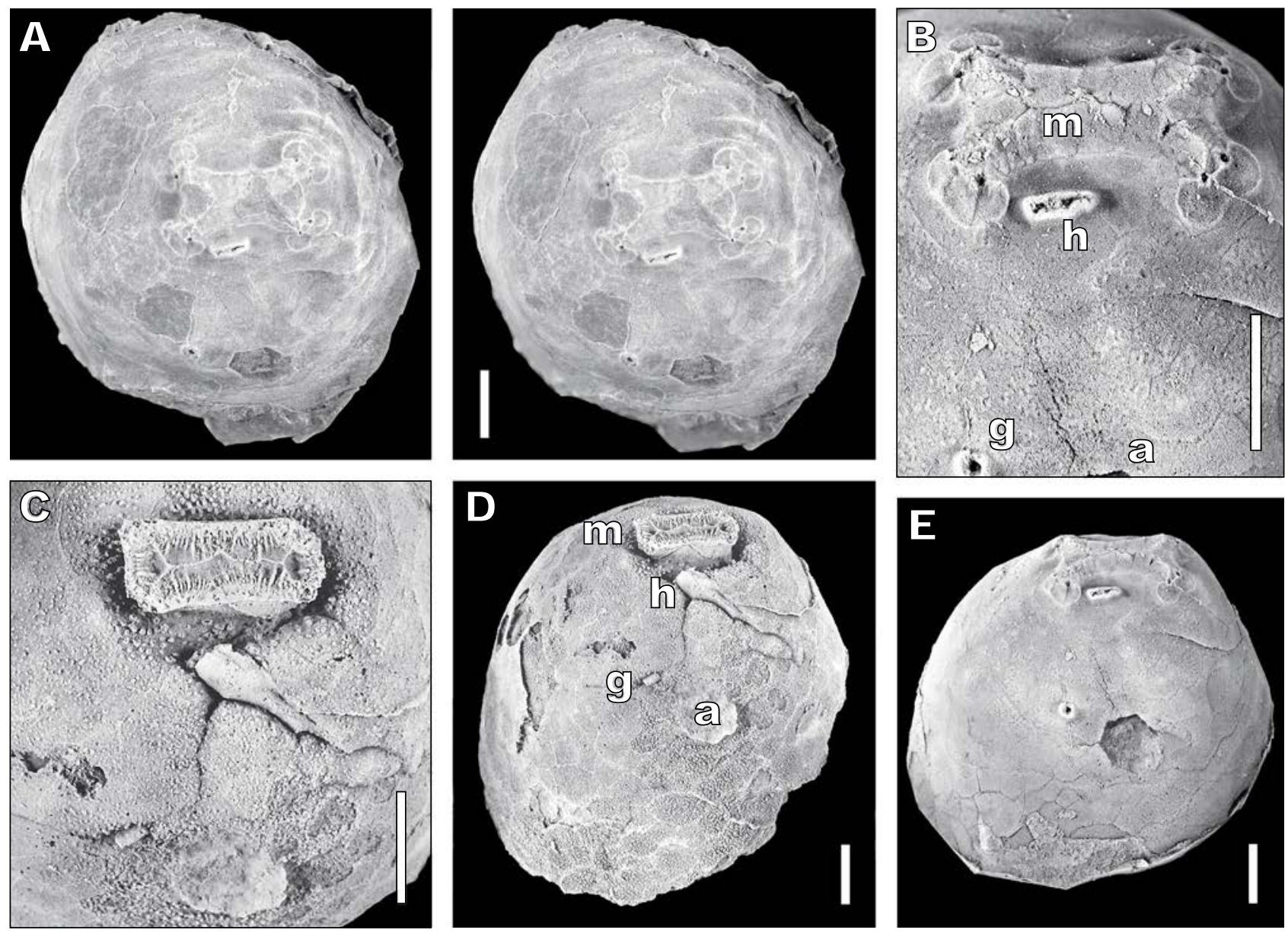

FIGURE 4. Photographs of Enodicalix gen. nov. A) Stereophotos of latex cast of MGM-2000-0, showing oral region and principal thecal orifices. B) Detail of the thecal orifices in the latex cast (a) periproct, (g) circular gonopore, (h) oval hydropore, (m) mouth with ambulacral cover plates. C) Detail of the oral area of the natural internal mould showing internal structures associated with the thecal orifices. D) Oblique view of internal mould to show impression of mouth $(\mathrm{m})$, stone canal leading to hydropore (h), possible gonoduct, septum associated with the gonopore ( $\mathrm{g}$ ) and cast of the periproct (a). E) Oblique general view of the latex cast showing separation of peristome and periproct. Scale bars $=5 \mathrm{~mm}$. A) whitened with fingerprint powder, B-E) with MgO.

The external thecal surface is entirely smooth. It shows only the faintest traces of either diplopores (Fig. 2C, D) or plate sutures (Fig. 4B right). The original presence of numerous diplopores is confirmed by the fill of the perpendicular canals on the internal mould (Figs. 2A, B; $4 \mathrm{C}$ especially near the mouth).

The internal moulds (Figs. 2A, B; 4C, D) reveal the overall shape of the theca and the presence of dense diplopores on all plates (Fig. 2) as well as the prominent rectangular 'donjon' around the mouth (m, Fig. 4D), the stone canal leading obliquely up towards the hydropore $(\mathrm{h}$, Fig. 4D), the rather inconspicuous gonoduct (g, Fig. 4D) and the fill of the periproct (a, Fig. 4D). There is also a trace of an internal mesentery connecting the hydropore and gonopore (Fig. 4C, D). Plate sutures and the fill of the perpendicular canals of the diplopores are much more obvious on the internal surface of the theca (Fig. 4C, D). The oral 'donjon' (Fig. 4C) shows the central suture between the cover plates, which clearly divides towards either end, reflecting the four ambulacra, but there is no evidence of a fifth ambulacrum internally (Fig. 4C) or externally (Figs. 3A; 4A, B).

\section{DISCUSSION}

Although plate sutures are not easy to detect, the plate arrangement around and over the mouth can be deduced (Figs. 1A; 3C). It shows the usual aristocystitid pattern of eight plates surrounding the mouth (Fig. 1A, B); four central peri-oral plates, two ( $\mathrm{PO} 3, \mathrm{PO} 4)$ on the anterior side and two (PO1, PO6) on the posterior side which share the Hydropore (H, Figs. 1A; 3B). At either end of the mouth are two pairs of circum-oral plates (Figs. 1A; 3C); CO1 bears the facets for ambulacrum $\mathrm{D}, \mathrm{CO} 2$ for ambulacrum E, $\mathrm{CO} 4$ for ambulacrum $\mathrm{B}$ and $\mathrm{CO} 5$ for ambulacrum $\mathrm{C}$. The oral cover plates are quite complex, but appear to 
show six large plates (1-6, Fig. 3C) that extend from the outer edge of the peristome to the central suture, one in each inter-ambulacrum and two in the posterior (CD) interambulacrum. These may represent the 'primary peristomial cover plates' of, for example, Sumrall and Waters (2012, fig. 1, p. 958), although those authors only recognized five such primary oral cover plates.

The nomenclature is not as secure as desirable. Meléndez (1958) based his species Calix inornatus on a unique type specimen that preserved only the aboral part of the theca and no trace of the external surface. He explicitly stated that he chose the trivial name 'inornatus' because the internal surface of the mould was smooth, apart from the casts of the perpendicular canals of the diplopores. By this we presume Meléndez was drawing attention to the fact that most other species that have been attributed to the genus Calix bear obvious spine-like plates, whereas his did not. Unfortunately, that does not help recognizing Meléndez's species, firstly because species of Calix with the spine-like plates often have smooth internal surfaces. See for example the internal and external surfaces of 'Calix rouaulti' illustrated by Chauvel and Meléndez (1978, pl. 1, figs. 1, 2). In addition, other genera of aristocystitids, such as Oretanocalix, also have smooth external surfaces. Thus, the unique specimen which exhibits the characters here attributed to the new genus, Enodicalix, can only tentatively be associated with the type specimen of 'Calix inornatus', its supposed type species.

\section{SUMMARY}

Re-examination of the critical specimen of 'Calix inornatus MELÉNDEZ, 1958, shows that it has four ambulacra, each of which terminates with a pair of equal ambulacral facets, side by side on, and flush with the surface of, single circum-oral plates. The oral area is elongate, covered by two series of larger outer and smaller central cover plates, within which small ambulacral orifices are developed adjacent to each facet. Posterior peri-oral plates PO1 and PO6 share an elongate hydropore set within an oval tubercle. The circular gonopore is developed within a single plate near the heptagonal periproct. These characteristics are typical of aristocystitid diploporites, but no currently described genus in this family has these precise characters. We therefore erect the new genus Enodicalix for 'Calix inornatus', which is currently the only known species in the genus.

\section{ACKNOWLEDGMENTS}

This paper is a contribution to the project CGL2017-87631-P of the Spanish Ministry of Science, Innovation and Universities, and
IGCP project 653 (IUGS-UNESCO). Carlos Alonso (Universidad Complutense de Madrid, Spain) photographed the specimens, except for Figure 3A. Comments from B. Lefebvre (Lyon) and an anonymous reviewer improved the original manuscript.

\section{REFERENCES}

Arroyo, F., Lara, R., 2002. Catálogo de las especies de equinodermos s.l. del Ordovícico español. Coloquios de Paleontología, 53, 87-108.

Chauvel, J., 1966. Échinodermes de l'Ordovicien du Maroc. Cahiers de Paléontologie, 1966, 1-120.

Chauvel, J., 1977. Calix sedgwicki Rouault (Echinoderme Cystö̈de, Ordovicien du Massif armoricain) et l'appareil ambulacraire des Diploporites. Comptes rendus sommaires de la Société Géologique de France, 1977, 314-317.

Chauvel, J., 1978. Compléments sur les Echinodermes $\mathrm{du}$ Paléozoïque marocain (Diploporites, Eocrinoïdes, Edrioastéroïdés). Notes du Service Géologique du Maroc, 39, 27-78.

Chauvel, J., Meléndez, B., 1978. Les Echinodermes (Cystoïdes, Asterozoaires, Homalozoaires) de l'Ordovicien Moyen des Monts de Tolède (Espagne). Estudios Geológicos, 34, 75-87.

Chauvel, J., Meléndez, B., 1986. Note complémentaire sur les Echinodermes ordoviciens de Sierra Morena. Estudios Geológicos, 42, 451-459.

Gil Cid, M.D., Bernal Barreiro, G.M., 1992. Aspectos paleoecológicos de una comunidad de Calyx (sic) del Ordovícico de los Montes de Toledo (España). Boletin Geológico y Minero, 103, 467-477.

Gil Cid, M.D., García Rincón, J.M., 2012. Thecal (oral zone) elements in cystoids from Spain. Neues Jahrbuch für Geologie und Paläontologie Abhandlungen, 264, 181-190. DOI: 10.1127/0077-7749/2012/0238

Gutiérrez-Marco, J.C., Chauvel, J., Meléndez, B., Smith, A.B., 1984. Los Equinodermos (Cystoidea, Homalozoa, Stelleroidea, Crinoidea) del Paleozoico Inferior de los Montes de Toledo y Sierra Morena (España). Estudios Geológicos, 40, 421-453.

Gutiérrez-Marco, J.C., 1993. Aspectos paleoecológicos de una comunidad de Calyx (sic) del Ordovícico de los Montes de Toledo: Discusión. Boletín Geológico y Minero, 104, 539-545.

Gutiérrez-Marco, J.C., Aceñolaza, G.F, 1999. Calix inornatus (Meléndez, 1958) (Echinodermata, Diploporita): morfología de la región oral de la teca y revisión bioestratigráfica. Temas Geológico-Mineros ITGE, 26, 557-565.

Gutiérrez-Marco, J.C., 2000. Revisión taxonómica de "Echinosphaerites" murchisoni Verneuil y Barrande, 1855 (Echinodermata, Diploporita) del Ordovícico Medio centroibérica (España). Geogaceta, 27, 83-86.

Gutiérrez-Marco, J.C., Colmenar, J., 2011. Biostratigraphy of the genus Calix (Echinodermata, Diploporita) in the Middle Ordovician of the southern Central Iberian Zone (Spain). In: Gutiérrez Marco, J.C., Rábano, I., García-Bellido, D. (eds.). 
Ordovician of the World. 11th International Symposium on the Ordovician System (ISOS), Spain, 2011. Cuadernos del Museo Geominero, 14, 189-197.

Lefebvre, B., Sumrall, C.D., Shroat-Lewis, R.A., Reich, M., Webster, G.D., Hunter, A.A., Nardin, E., Rozhnov, S.V., Guensburg, T.E., Touzeau, A., Noailles, F., Sprinkle, J., 2013. Palaeobiogeography of Ordovician echinoderms. In: Harper, D.A.T., Servais, T. (eds.). Early Palaeozoic Biogeography and Palaeogeography. Geological Society, London, Memoirs, 38, 173-198. DOI: 10.1144/M38.14

Makhlouf, Y., Lefebvre, B., Nardin, E., Nedjari, A., Paul, C.R.C., 2017. Lepidocalix pulcher Termier and Termier, 1950 (Echinodermata, Diploporita) from the Middle Ordovician of northern Algeria: taxonomic revision and palaeoecological implications. Acta Palaeontologica Polonica, 62, 299-310. DOI: 10.4202/app.00286.2016

McDermott, P.D., Paul, C.R.C., 2019. A new Upper Ordovician aristocystitid diploporite genus (Echinodermata) from the Llanddowror district, South Wales. Geological Journal, 54, 529-536. DOI: 10.1002/gj.3203

Meléndez, B., 1958. Nuevo Cistideo del Ordoviciense de los Montes de Toledo. Notas y Comunicaciones del Instituto Geológico y Minero de España, 50, 323-328.

Meléndez, B., Chauvel, J., 1983. Nuevos cistideos del Ordovícico de los Montes de Toledo. In: Comba, J.A. (Coordinator) Libro Jubilar J.M. Ríos. Contribuciones sobre temas generales. Instituto Geológico y Minero de España, 3, 151-155.

Neumayr, M., 1889. Die Stämme des Thierreiches. 1. Wirbellose Thiere. Tempsky, Vienna and Prague, 603pp.
Paul, C.R.C., 1973. British Ordovician Cystoids, part 1, Monographs of the Palaeontographical Society, 127(536), 1-64.

Paul, C.R.C., 2017. Testing for homologies in the axial skeleton of primitive echinoderms. Journal of Paleontology, 91, 582-603. DOI: $10.1017 /$ jpa.2016.151

Paul, C.R.C., 2018. Prokopius, a new name for "Hippocystis sculptus": Prokop, 1965, and the status of the genus Hippocystis Bather, 1919 (Echinodermata; Diploporita). Bulletin of Geosciences, 93, 337-346. DOI: 10.3140/bull. geosci. 1697

Rábano, I., 1985. Precisiones sobre los trilobites del Arroyo Acebrón (Ventas con Peña Aguilera, Toledo). Coloquios de Paleontología, 40, 9-17.

Reed, F.R.C., 1917. Ordovician and Silurian fossils from Yun-nan. Memoirs of the Geological Survey of India, Palaeontographica Indica, new series, 6, 1-69.

Rouault, M., 1851. Mémoire sur le terrain paléozoïque des environs de Rennes. Bulletin de la Société géologique de France, série 2, 8, 358-399.

Sumrall, C.D., Waters, J.A., 2012. Universal elemental homology in glyptocystitoids, hemicosmitoids, coronoids and blastoids: steps towards echinoderm phylogenetic reconstruction in derived Blastozoa. Journal of Paleontology, 86, 956-972.

Termier, H., Termier, G., 1950. Contribution à l'étude des faunes paléozoïques de l'Algérie. Bulletin du Service de la Carte Géologique de l'Algérie, 79, 1-83.

Tillman, C.G., 1967. Triamara cutleri, a new cystoid from the Osgood Formation (Silurian) of Indiana. Journal of Paleontology, 41, 222-226.

Manuscript received April 2019;

revision accepted November 2019;

published Online February 2020. 